\title{
Cows' milk fat and human nutrition
}

\section{By J. H. Moore, The Hannah Research Institute, Ayr, Scotland $\mathrm{KA6}{ }_{5} \mathrm{HL}$}

\section{Composition of milk fat}

Cows' milk fat consists mainly of triglycerides $(98-99 \mathrm{~g} / \mathrm{100} \mathrm{g})$ together with smaller amounts of phospholipids $(0.9 \mathrm{~g} / 100 \mathrm{~g})$, cholesterol $(0.3 \mathrm{~g} / 100 \mathrm{~g})$, carotenoids $(6-7 \mu \mathrm{g} / \mathrm{g})$, vitamin A $(6-8 \mu \mathrm{g} / \mathrm{g})$, vitamin $\mathrm{D} \quad(0.5 \mu \mathrm{g}$ cholecalciferol $/ \mathrm{roo} \mathrm{g}$ ) and trace concentrations of other fat-soluble substances such as lanosterol, $\beta$-sitosterol, saturated hydrocarbons, squalene, glyceryl ethers and vitamin K (Kon, 1972; Kuzdzal-Savoie, Kuzdzal, Langlois \& Trehin, 1973). The composition of human milk fat is similar to that of cows' milk fat. Many analyses have been reported for the fatty acid compositions of cows' and human milk fat, but the representative values given (as weight percentages) by Patton, McCarthy, Evans \& Lynn (1960) and Breckenridge, Marai \& Kuksis (1969) will be used in the following comparison. Saturated acids from 4:0 to 10:0 account for about $9 \%$ of the fatty acids in cows' milk fat, but are not normally detected as components of human milk fat. In cows' milk fat the contents of $12: 0(3 \%)$ and $16: 1(1 \%)$ are usually somewhat smaller, and the content of $14: 0(12 \%)$ is usually somewhat greater than in human milk fat $(12: 0,5.6 \%, 16: 1,3.3 \% ; 14: 0,7.0 \%)$. The concentrations of $16: 0(25 \%)$ and $18: 1(31 \%)$ in cows' milk fat produced in the summer months are similar to the corresponding concentrations observed in human milk fat, but cows' milk fat produced in the winter months contains greater concentrations of $16: 0(34 \%)$ and smaller concentrations of $18: 1$ (22\%). Invariably, cows' milk fat contains greater concentrations of $18: 0$ (14\%) but much smaller concentrations of $18: 2(1.6 \%)$ than does human milk fat $(18: 0,6 \% ; 18: 2$, 10\%). Human milk fat may contain up to $1 \%$ 20:4 whereas cows' milk fat contains only trace concentrations of this tetraenoic acid.

Because of the importance of certain unsaturated fatty acids in nutrition and metabolism it is necessary to examine in some detail the nature of the unsaturated fatty acids in cows' milk fat. The diet of the cow normally contains appreciable amounts of oleic acid (18:1 cis-9 or $18: 1$ ( $n-9)$ ), linoleic acid (18:2 cis-9,cis-12 or $18: 2(n-6))$ and linolenic acid (18:2 cis-9,cis-15 or $18: 3(n-3))$ but these dietary unsaturated acids are extensively hydrogenated by the microorganisms in the rumen. The mechanisms involved in these ruminal biohydrogenation processes are complex and result in the formation of a variety of trans isomers such as $18: 2$ cis-9,trans-1 I, 18:2 trans-I I,cis-1 5, I8:1 trans-1 I and 18:1 trans-9 which are absorbed from the intestine and are incorporated into ruminant tissue and milk lipids (see reviews by Dawson \& Kemp, 1970; Viviani, 1970; Moore, 1974). The concentration of trans isomers in cows' milk fat varies considerably with the diet and the efficiency of the hydrogenation process operating in the rumen under a 
given set of conditions (Steele, Noble \& Moore, 1971). However, from various values given in the literature (Jensen, Quinn, Carpenter \& Sampugna, 1967; Morrison, I970; Strocchi \& Holman, 1971; Jensen, I973; Patton \& Jensen, 1976; Parodi, 1977) it may be calculated that about $7.5 \%$ of the total fatty acids in cows' milk fat have unsaturated bonds with the trans configuration.

It has been estimated that about $90 \%$ of dietary unsaturated fatty acids are hydrogenated in the rumen (Bickerstaffe, Noakes \& Annison, 1972), and this is undoubtedly a major factor that determines the relatively small concentration of polyunsaturated fatty acids in cows' milk fat. Differences in the effectiveness of the biohydrogenation process in the rumen will influence the total 18:2 content of cows' milk fat which may vary from 0.7 to $3.9 \%$ of the total fatty acids (Ahrens, Hirsch, Insull, Tsaltas, Blomstrand \& Peterson, 1957; Taylor \& Hawke, 1975a). However, from a nutritional point of view, it is much more important to know the concentration of the biologically active $18: 2$ cis-9,cis- 12 in milk fat. From the results given by White $\&$ Brown (r 949), Thomasson (r 953), Sambasivaro \& Brown (1962), Herb, Magidman, Luddy \& Riemenschneider (1962), Strocchi \& Holman (1971) and Kiuri, Leppanen \& Antila (1974) it would appear that the proportion of $18: 2$ cis-9, cis-12 in the total $18: 2$ of cows' milk fat varies from 50 to $70 \%$; this variation is probably a reflection of differences in the pattern of the hydrogenation reactions that function in the rumen under different dietary conditions.

Detailed investigations into the structure of the triglyceride fraction of cows' milk have been reported by Blank \& Privett (1964), Jensen \& Sampugna (1966), Nutter \& Privett (1967), Pitas, Sampugna \& Jensen (1967), Breckenridge \& Kuksis $(1968 a, b, 1969)$ and Taylor \& Hawke (1975a,b). These investigations have shown that $4: 0$ and $6: 0$ are esterified predominantly in position $3,8: 0$ in positions 2 and $3,10: 0,12: 0,14: 0$ and $18: 2$ in position 2 , and $16: 1,18: 0$ and $18: 1$ in position 1 . There are pronounced differences in the structure of the triglycerides in cows' milk and human milk, for in the triglycerides of human milk $12: 0,16: 1$ and $18: 2$ are esterified predominantly in position $3,14: 0$ in positions 2 and $3,16: 0$ in position 2 , $18: 0$ in position $I$ and $18: I$ in positions $I$ and 3 (Breckenridge et al. 1969 ).

\section{Dietary intake of milk fat in the United Kingdom}

The recently published Annual Report of the National Food Survey Committee of the Ministry of Agriculture, Fisheries and Food (1976) shows that for the United Kingdom, the total dietary intake of fat amounts to about ro5 $\mathrm{g} /$ person per $\mathrm{d}$, which accounts for $42 \%$ of the total intake of dietary energy. Millk, butter and other dairy products account for $36 \%$ ( $38 \mathrm{~g} /$ person per d) of the total fat intake, $47 \%(24 \mathrm{~g} /$ person per $\mathrm{d}$ ) of the total saturated fat intake, $29 \%(\mathrm{Ir} \cdot 5 \mathrm{~g} / \mathrm{person}$ per d) of the total monounsaturated fatty acid intake, but only $9.3 \%(0.96$ $\mathrm{g} /$ person per $\mathrm{d}$ ) of the total polyunsaturated fatty acid intake. Milk, butter and other dairy products also account for $30 \%(44 \mathrm{I} \mu \mathrm{g}$ retinol equivalent/person per d) of the total vitamin $A$ intake and for $21 \%(0.57 \mu \mathrm{g}$ cholecalciferol equivalent/ 
person per d) of the total vitamin $\mathrm{D}$ intake. The dietary intake of cholesterol from milk, butter and other dairy products amounts to about I $5 \mathrm{mg} /$ person per $\mathrm{d}$.

\section{Digestion and absorption of milk fat}

Although investigations with adult man have shown that most common dietary fats, including cows' milk fat, are digested and absorbed with considerable efficiency (Deuel, 1955), there is some variation in the efficiency with which the human infant digests and absorbs different fats. For example from a study with premature infants, Tidwell, Holt, Farrow \& Neale (1935) reported digestibility coefficients of $77 \%$ for olive oil but only $58 \%$ for cows' milk fat. Moreover, the human infant digests and absorbs human milk fat more efficiently than it does cows' milk fat or mixtures of vegetable and animal fats, even when these mixtures have been formulated specifically to resemble human milk fat in fatty acid composition (Tomarelli, Meyer, Weaber \& Bernhart, 1968). Palmitic acid (16:0) is a major component of many dietary fats and the possibility that differences in the digestibilities of these dietary fats might be related to differences in the positional distribution of 16:0 within the triglyceride molecule was first suggested by Mattson \& Volpenhein (1962) who found from experiments with rats that the intestinal absorption of 16:0 from glyceryl 2-palmitoyl 1,3-dioleate was much greater than it was from glyceryl I-palmitoyl 2,3-dioleate. In an investigation with chicks Renner \& Hill ( 1964 ) observed that $95 \%$ of the $16: 0$ in lard was absorbed from the intestine but only $80 \%$ of the $16: 0$ in randomized lard, i.e. lard in which the positional distribution of the constituent fatty acids had been completely randomized by treatment with sodium ethoxide. Renner \& Hill (1964) also observed that monopalmitin was absorbed to a much greater extent than was free 16:0. Lard resembles human milk fat in that high proportions (about 85 and $70 \%$ respectively) of the constituent $16: 0$ is esterified in position 2 of the triglyceride molecules, whereas only about $40 \%$ of the total $16: 0$ is esterified in position 2 of the triglycerides in cows' milk fat. Since pancreatic lipase specifically hydrolyses the primary ester linkages of triglycerides (Mattson \& Beck, 1956), dietary lard or human milk fat would be expected to give rise to high concentrations of the polar and readily absorbable 2-monopalmitin in the contents of the small intestine; in contrast, the hydrolysis of dietary cows' milk fat would give rise to high concentrations of the less polar and less readily absorbable 16:0. Support for this concept was obtained by Tomarelli et al. (1968) who conducted fat absorption studies with rats given diets containing human milk fat, cows' milk fat, lard and various blends of vegetable oils formulated to resemble human milk fat in fatty acid composition and in the positional distribution of $16: 0$. There was a positive linear relationship between the efficiency with which 16:0 was absorbed and the proportion of the total $16: 0$ that was esterified in position 2 of the various dietary fats. Unsaturated and short-chain fatty acids were well absorbed irrespective of their positional distribution within the triglyceride molecule. Similar results were obtained by Filer, Mattson \& Fomon (1969) from experiments with human infants 
given diets containing lard or randomized lard. It seems reasonable to conclude therefore that the ability of the human infant to digest and absorb human milk fat more efficiently than cows' milk fat is due to the difference in the positional distribution of $16: 0$ within the triglyceride molecules of these two dietary fats. The fact that this difference is more apparent in infants than it is in adults may be due to the suboptimal conditions for the formation of mixed micelles that appear to exist in the small intestinal contents of infants. According to Norman, Strandvik \& Ojamae (1972), the concentration of bile salts in small intestinal contents of infants is only about one-sixth of that observed in adults; in the presence of such low concentrations of bile salts it may be envisaged that glyceryl 2-monopalmitin would be incorporated more readily into the micellar phase than would 16:0.

\section{Nutritional significance of trans unsaturated fatty acids in cows' milk fat}

Although the results of Holman \& Aaes-Jorgensen (1956) suggested that dietary trans isomers of $18: 2$ interfered with the normal utilization by rats of the essential fatty acid $18: 2$ cis-9,cis-12, these results were somewhat limited by the very small numbers of rats allocated to the dietary treatments. Indeed, subsequent work has failed to confirm the results of Holman \& Aaes-Jorgensen (1956) and it seems clear that when diets contain adequate levels of $18: 2$ cis-9,cis- 12 , the utilization of this essential fatty acid, as measured by growth rate and general health of experimental animals, is not inhibited by supplementing the diets with trans isomers of $18: 1$ or with cis,trans or trans,trans isomers of $18: 2$ (Alfin-Slater, Aftergood, Bingemann, Kryder \& Deuel, 1957; Mattson, 1960). The essentiality of dietary 18:2 cis-9,cis-12 is intimately associated with its conversion to 20:4 all-cis in animal tissues, and it is important to know whether this conversion is impaired when the diet contains trans isomers of $18: 1$ and $18: 2$. The results obtained from several animal experiments have shown that the synthesis of $20: 4$ all-cis from $18: 2$ cis-9,cis-12 is only partially inhibited when the diet contains up to $4 \%$ of the $18: 2$ isomer with two trans double bonds, and not at all when the diet contains similar concentrations of $18: 2$ isomers with only one trans double bond (Privett \& Blank, 1964; Selinger \& Holman, 1965; Privett, Stearns \& Nickell, 1967; Anderson, Fullmer \& Hollenbach, 1975; Privett, Phillips, Shimasaki, Nozawa \& Nickell, 1977) or trans isomers of $18: 1$ (Decker \& Mertz, 1966; Privett et al. 1977).

The work of Chapman, Owens \& Walker (1966) indicated that differences in molecular shape between geometrical isomers of unsaturated fatty acids could result in changes in the structure and function of biomembranes containing glycerophosphatides with trans unsaturated fatty acids esterified in position 2 . It is perhaps fortunate therefore that dietary $18: 1$ trans -9 is preferentially incorporated into the 1-position of phosphatidyl choline and phosphatidyl ethanolamine of rat liver (Egwim \& Sgoutas, 1971). Nevertheless, there is evidence that cis,trans isomers of $18: 2$ can be incorporated into the 2-position of rat liver phosphatidyl choline (Lands, Blank, Nutter \& Privett, 1966). However, it must be pointed out that the incorporation of $18: 2$ cis-9,trans-12 into position 2 of rat liver phosphatidyl choline in vivo occurred in highly abnormal circumstances, i.e. the 
rats were first depleted of $18: 2$ cis-9,cis- 12 and were then given a diet containing a relatively large content ( $5 \%$ ) of $18: 2$ cis-9,trans- 12 .

The results obtained by many groups of research workers have shown that diets containing high levels of 'saturated' fat result in hypercholesterolaemia in man and a variety of experimental animals (see Vergroesen \& Gottenbos, 1975). As pointed out by Jackson, Morrisett, Pownall, Gotto, Kamio, Imai, Tracey \& Kummerow (1977), many of the 'saturated' fats used in these experiments were commercially hydrogenated vegetable oils that would almost certainly contain some trans unsaturated fatty acids, and it seems reasonable to enquire whether the presence of these geometrical isomers contribute in any way to the hypercholesterolaemic properties of such dietary fats. However, investigations with man (Grasso, Gunning, Imaichi, Michaels \& Kinsella, 1962; Erickson, Coots, Mattson \& Kligman, 1964; Mattson, Hollenbach \& Kligman, r975; Vergroesen \& Gottenbos, 1975) and with experimental animals (Weigensberg, McMillan \& Ritchie, 196r; Barnes, Kwong, Mattick \& Loosli, 196r; Weigensberg \& McMillan, r964; McMillan, Silver \& Weigensberg, 1965; Rand \& Quackenbush, 1965; Schrock \& Connor, 1975) indicate that inclusions of relatively high concentrations of trans isomers of $18: 1$ or $18: 2$ in the diet have little or no effect on plasma cholesterol or triglyceride levels.

Thus it seems reasonable to conclude that no untoward effects on metabolism are likely to result from the relatively small contribution that is made by cows' milk fat to the content of trans isomers of unsaturated fatty acids in the diet of man. In the United Kingdom the total fat intake from dietary milk, butter and other dairy products is equivalent to about $15 \%$ of the total dietary energy (Ministry of Agriculture, Fisheries \& Food, 1976). It may be calculated therefore that the $18: 1$ trans, $18: 2$ cis,trans and $18: 2$ trans,trans derived from cows' milk fat contribute only about $1 \cdot 0,0.06$ and $0.009 \%$ respectively of the total dietary energy. Even in infants reared solely on cows' milk, $18: 1$ trans, $18: 2$ cis,trans and $18: 2$ trans,trans would provide only about $3.4,0.21$ and $0.03 \%$ of the total dietary energy.

\section{Essential fatty acids in cows' milk and infant nutrition}

The essentiality of polyunsaturated fatty acids of the $(n-6)$ series, e.g. linoleic acid, I8:2 (n-6), and arachidonic acid, 20:4 (n-6), has been fully established, and the exclusion of these fatty acids from the diets of man and experimental animals results in the appearance of well characterized deficiency symptoms (Holman, 1971 $a, b)$. Although polyunsaturated fatty acids of the $(n-3)$ series, e.g. linolenic acid, 18:3 (n-3), are often classified as essential fatty acids for man and other mammals, there is at present no convincing evidence that this is so (Holman, 1971 $a, b$; Houtsmuller, 1973, 1975). The trienoic acid, 20:3 (n-9) characteristically accumulates in the tissues of animals deprived of essential fatty acids (Mead, 1971). In experiments with rats, Mohrhauer \& Holman (1963a) found that there was a curvilinear relationship between the degree of dermatitis (dermal score) and the 20:3 $(n-9) / 20: 4(n-6)$ (triene:tetraene) in the tissues showing that external signs 
of essential fatty acid deficiency did not appear until the triene:tetraene in the tissues exceeded 0.4 ; such values were attained when 18:2 $(n-6)$ contributed less than $1 \%$ of the total dietary energy for male rats and less than about $0.6 \%$ of the total dietary energy for female rats (Pudelkewicz, Seufert \& Holman, 1968). The triene:tetraene ratio in the tissues has now been used successfully to assess the essential fatty acid status of a number of non-ruminant animals (see Moore \& Noble, 1975) and in general it would appear that the minimum dietary requirement is met when $18: 2$ constitutes $1 \%$ or more of the total energy. However, as Holman $(197 \mathrm{I} b)$ has pointed out, the triene:tetraene in the tissues is not an infallible measure of essential fatty acid deficiency. For example it should be emphasized that the correlation between triene:tetraene in the tissues and essential fatty acid status is valid only when the relationship between dermal score, triene tetraene in the tissues and the $18: 2(n-6)$ content of the diet has reached a steady state. Thus, when weanling rats were given a diet deficient in essential fatty acids, the triene:tetraene in the tissues increased above 0.4 after about $20 \mathrm{~d}$, but skin lesions were not evident until after $40 \mathrm{~d}$; maximum dermal scores and triene:tetraene in the tissues were not observed until after about $70 \mathrm{~d}$ (Holman, 1971 $b$; AaesJorgensen \& Holman, 1958; Mohrhauer \& Holman, 1963a).

It is perhaps not surprising that there have been no reports of clinical or biochemical evidence of essential fatty acid deficiency in adult human subjects given low-fat diets. Adult rats must be given a completely fat-free diet for at least 3 months, i.e. about $16 \%$ of their average life span, before external signs of essential fatty acid deficiency begin to appear. It may be argued therefore that an adult man would have to be given a fat-free diet for ro years or more before essential fatty acid deficiency could be expected to develop (Soderhjelm, Wiese \& Holman, 1971). Since the stores of essential fatty acids in the tissues of infants are so much smaller than those of adults the effects of diets deficient in $18: 2(n-6)$ are more pronounced in children than they are in adults, and most of the available information on the role and requirement of essential fatty acids in human nutrition has been obtained from investigations with children (Soderhjelm et al. 197I). In an attempt to define the role of $18: 2(n-6)$ in infant nutrition Hansen, Wiese, Boelshe, Haggard, Adam \& Davis $(1963)$ conducted a clinical and biochemical study of 428 subjects given one of five liquid diets that varied in $18: 2$ content. The negative curvilinear relationship between the $18: 2$ contents of the diets and the triene:tetraene in the serum of the infants at 3 months of age (see Holman, Castor \& Wiese, 1964) was almost identical to that obtained between the triene:tetraene in the plasma of rats and the $18: 2$ contents of their diets (Holman, $1971 b$ ). Moreover, the inverse curvilinear relationship between the incidence of skin disorders of the infants at 3 months of age and the 18:2 contents of the various diets (Hansen et al. 1963) was very similar to that observed by Mohrhauer \& Holman $\left(\mathrm{r}^{2} 6_{3} b\right)$ between the dermal score in rats and the $18: 2$ contents of their diets. Thus it appeared that in both the rat and human infant external signs of essential fatty acid deficiency began to appear when the triene:tetraene in the plasma or serum increased above 0.4 , and when the diet provided less than about $1 \%$ of its total energy as $18: 2$; however, in 
both species, the most pronounced increases in the incidence of skin disorders and in the plasma or serum triene:tetraene occurred when $18: 2$ contributed less than about $0.6 \%$ of the total dietary energy. Woodruff, Bailey, Davis, Rogers \& Coniglio (1964), Holman, Hayes, Rinne \& Soderhjelm (1965) and Pikaar \& Fernandes (1966) have compared the triene:tetraene in the serum of infants given cows' milk or human milk during the first 3 months of life; in the serum of infants given human milk the triene:tetraene were less than 0.4 , but in the infants given cows' milk the serum triene:tetraene ratios were greater than 0.4 , although none of these infants exhibited any external signs of essential fatty acid deficiency.

Variation in the mechanism and efficiency of ruminal biohydrogenation will result in some variation in the total $18: 2$ content $(0.7$ to $3.9 \%)$ and in the proportion of $18: 2(n-6)$ in the total $18: 2(50$ to $70 \%)$ of cow's mill fatty acids. From the extreme values that have been reported in the literature it may be calculated that $18: 2(n-6)$ may contribute from 0.2 to $1.6 \%$ of the total energy in cows' milk; however, a more representative value would be $0.6 \%$ of the total energy, assuming that $18: 2(n-6)$ normally accounts for about $1.6 \%$ of the total fatty acids and that $18: 2(n-6)$ normally accounts for about $65 \%$ of the total I8:2. It might be argued therefore that some cows' milks would supply slightly more than the minimum requirement of essential fatty acids for the human infant whereas others would supply slightly less, but it is clear that marginally deficient milks would have to be given to infants for a prolonged period before clinical signs of essential fatty acid deficiency would begin to appear. It must be remembered also that in the United Kingdom, preparations of cereals, fruit, vegetables and meat, all containing essential fatty acids, are introduced into the diet of infants usually before the age of 3 months. In view of the absence of external symptoms of essential fatty acid deficiency in infants reared on cows' milk preparations, Cuthbertson (1976) has questioned whether the essential fatty acid requirement of infants has been overestimated. However, Horecny (1968) noted that the macroscopic changes in the skin of infants given diets deficient in essential fatty acids are preceded by well-characterized histological changes. These histological changes were observed in skin biopsy material obtained from infants given cows' milk, but not in skin samples obtained from infants given human milk or cows' milk supplemented with soya-bean oil; at the time the skin biopsy material was taken, none of the infants exhibited any external symptoms of essential fatty acid deficiency.

In spite of the absence of gross skin disorders in infants reared on cows' milk, it would seem unwise to allow the human infant to exist, even for a short period, on a diet that may provide insufficient essential fatty acids for the optimum development and function of cellular membranes. To allow for those milks that are marginally deficient in essential fatty acids, it would seem prudent to add 18:2 $(n-6)$ to all cows' milks that are to be used in infant nutrition. According to Hansen et al. (1963) and Soderhjelm et al. (1971) a diet in which $18: 2$ (n-6) constitutes $4 \%$ of the total energy provides an optimum intake of essential fatty acids for the human infant. This level of $18: 2(n-6)$ could be achieved simply by supplementing cows' 
milk with maize oil (which also contains native tocopherols), for example at the rate of about $600 \mathrm{mg}$ per $100 \mathrm{ml}$; the concentration of $18: 2(n-6)$ in the total fatty acids in such supplemented cows' milk would be similar to that observed for human milk (Soderhjelm et al. 1971). As pointed out by Soderhjelm et al. (197r), there would seem to be no special advantage in supplying $18: 2(n-6)$ at levels equivalent to more than $4 \%$ of the total dietary energy. Moreover, there is evidence that infants given diets in which $18: 2(n-6)$ constitutes $28 \%$ or more of the total fatty acids must also be given a supplement of $60 \mathrm{mg}$ of $a$-tocopherol/d to allow for the increased requirement of vitamin $\mathrm{E}$ (Hassan, Hashim, Van Itallie \& Sebrell, 1966).

\section{REFERENCES}

Aaes-Jorgensen, E. \& Holman, R. T. (1958). $\mathscr{~}$. Nutr. 65, 633 .

Ahrens, E. H., Hirsch, J., Insull, W., Tsaltas, T. T., Blomstrand, R. \& Peterson, M. L. (1957). Lancet i, 943 .

Alfin-Slater, R. B., Aftergood, L., Bingemann, L., Kryder, G. D. \& Deuel, H. J. (1957). Proc. Soc. exp. Biol. Med. 95, 521 .

Anderson, R. L., Fullmer, C. S. \& Hollenbach, E. J. (1975). F. Nutr. 105, 393.

Barnes, R. H., Kwong, E., Mattick, L. R. \& Loosli, J. K. (1961). Proc. Soc. exp. Biol. Med. ro8, 468.

Bickerstaffe, R., Noakes, D. E. \& Annison, E. F. (1972). Biochem. J. 130, 607.

Blank, M. L. \& Privett, O. S. (1964). Y. Dairy Sci. 47, 48 I.

Breckenridge, W. C. \& Kuksis, A. (1968a). Lipids 3, 291.

Breckenridge, W. C. \& Kuksis, A. (1968b). Y. Lipid Res. 9, 388.

Breckenridge, W. C. \& Kuksis, A. (1969). Lipids, 4, 197.

Breckenridge, W. C., Marai, L. \& Kuksis, A. (1969). Can. F. Biochem. 47, 761.

Chapman, D., Owens, N. F. \& Walker, D. A. (1966). Biochem. biophys. Acta 120, 148.

Cuthbertson, W. F. J. (1976). Am. F. clin. Nutr. 29, 559 .

Dawson, R. M. C. \& Kemp, P. (1970). In Physiology of Digestion and Metabolism in the Ruminant, p. 504 [A. T. Phillipson, editor]. Newcastle upon Tyne: Oriel Press

Decker, W. J. \& Mertz, W. (1966). F. Nutr. 89, 165.

Deuel, H. J. (1955). In The Lipids, vol. 2, p. 216 . New York: Interscience Publishers.

Egwim, P. O. \& Sgoutas, D. S. (1971). F. Nutr. 101, 307.

Erickson, B. A., Coots, R. H., Mattson, F. H. \& Kligman, A. M. (1964). F. clin. Invest. 43, 2017.

Filer, L. J., Mattson, F. H. \& Fomon, S. J. (1969). F. Nutr. 99, 293.

Grasso, S., Gunning, B., Imaichi, K., Michaels, G. \& Kinsella, L. (1962). Metabolism I I, 920.

Hansen, A. E., Wiese, H. F., Boelshe, A. N., Haggard, M. E., Adam, D. J. D. \& Davis, H. (1963). Paediatrics 31, (suppl.) I $7 \mathrm{I}$.

Hassan, H., Hashim, S. A., Van Itallie, T. B. \& Sebrell, W. H. (1966). Am. J. clin. Nutr. 19, 147.

Herb, S. F., Magidman, P. Luddy, F. E. \& Riemenschneider, R. W. (1962). F. Am. Oil Chem. Soc. 39, 142.

Holman, R. T. (1971a). In Progress in the Chemistry of Fats and other Lipids, vol. 9, p. 279. Oxford: Pergamon Press.

Holman, R. T. (1971 b). In Progress in the Chemistry of Fats and other Lipids, vol. 9, p. 607. Oxford: Pergamon Press.

Holman, R. T. \& Aaes-Jorgensen, E. (1956). Proc. Soc. exp. Biol. Med. 93, 175.

Holman, R. T., Castor, W. O. \& Wiese, H. F. (1964). Am. Y. clin. Nutr. $14,70$.

Holman, R. T., Hayes, H. W., Rinne, A. \& Soderhjelm, L. (1965). Acta paediat., Stockh. 54, 573.

Horecny, K. (1968). Mscht. Kinderheilk. 116, 433.

Houtsmuller, U. M. T. (1973). In Dietary Lipids and Postnatal Development, p. 145 [C. Galli, G. Jacini \& A. Pecile, editors]. New York: Raven Press.

Houtsmuller, U. M. T. (1975). In The Role of Fats in Human Nutrition, p. 33 I [A. J. Vergroesen, editor]. New York: Academic Press.

Jackson, R. L., Morrisett, J. D., Pownall, H. J., Gotto, A. M., Kamio, A., Imai, H., Tracey, R. \& Kummerow, F. A. (1977). J. Lipid Res. 18, 182. 
Jensen, R. G. (1973). F. Am. Oil Chem. Soc. 50, 186.

Jensen, R. G., Quinn, J. G., Carpenter, D. L. \& Sampugna, J. (1967). J. Dairy Sci. 50, 1 r 9.

Jensen, R. G. \& Sampugna, J. (I 966), F. Dairy Sci. 49, 460.

Kiuri, K., Leppanen, R. \& Antila, M. (1974). Fette Seifen 76, 401.

Kon, S. K. (1972). Milk and Milk Products in Human Nutrition, and edition, p. 1. Rome: Food and Agriculture Organization of the United Nations.

Kuzdzal-Savoie, S., Kuzdzal, W., Langlois, D. \& Trehin, J. (1973). In Dietary Lipids and Postnatal Development, p. I [G. Galli, G. Jacini \& A. Pecile, editors]. New York: Raven Press.

Lamptey, M. S. \& Walker, B. L. (1976). $\mathcal{f}$. Nutr. 106, 88.

Lands, W. E. M., Blank, M. L., Nutter, L. J. \& Privett, O. S. (1966). Lipids, I, 224.

McMillan, G. C., Silver, M. D. \& Weigensberg, B. I. (1965). Archs. Path. 76, 106.

Mattson, F. H. (1960). F. Nutr. 7x, 366 .

Mattson, F. H. \& Beck, L. W. (1956). Y. biol. Chem. 219, 735 .

Mattson, F. H., Hollenbach, E. J. \& Kligman, A. M. (I975). Am. J. clin. Nutr. 28, 726.

Mattson, F. H. \& Volpenhein, R. A. (1962). F. biol. Chem. 237, 53.

Mead, J. F. (1971). In Progress in the Chemistry of Fats and other Lipids, vol. 9, p. 159 [R. T. Holman, editor]. Oxford: Pergamon Press.

Ministry of Agriculture, Fisheries and Food. (1976). Household Food Consumption and Expenditure: 1976; Annual Report of the National Food Survey Committee. London: H. M. Stationery Office.

Mohrhauer, H. \& Holman, R. T. (1963a). F. Lipid Res. 4, 151 .

Mohrhauer, H. \& Holman, R. T. $(1963 b)$. In Biochemical Problems of Lipids, B. B. A. Library, vol. 1, p. $44^{6}$ [A. C. Frazer, editor]. Amsterdam: Elsevier.

Moore, J. H. (1974). In Industrial Aspects of Biochemistry, vol. 2, p. 835 [B. Spencer, editor]. Amsterdam: North Holland.

Moore, J. H. \& Noble, R. C. (1975). In Digestion and Metabolism in the Ruminant, p. 465 [I. W. MacDonald \& A. C. I. Warner, editors]. Armidale, Australia: University of New England Press.

Morrison, W. R. (1970). In Tropics in Lipid Chemistry, vol. I, p. 51 [ F. D. Gunstone, editor]. London: Logos.

Norman, A., Strandvik, B. \& Ojamae, O. (1972). Acta Paediat., Stockh. 6r, 571.

Nutter, L. J. \& Privett, O. S. (1967). F. Dairy Sci. 50, 1194.

Parodi, P. W. (1977). F. Dairy Sci. 60, $155^{\circ}$.

Patton, S. \& Jensen, R. G. (1976). In Biomedical Aspects of Lactation, p. 77. Oxford: Pergamon Press.

Patton, S., McCarthy, R. D., Evans, L. \& Lynn, T. R. (1960). J. Dairy Sci. 43, 1187.

Pikaar, N. A. \& Fernandes, J. (1966). Am. Y. clin. Nutr. 19, 194.

Pitas, R. E., Sampugna, J. \& Jensen, R. G. (1967). F. Dairy Sci. 50, 1332.

Privett, O. S. \& Blank, M. L. (1964). F. Am. Oil Chem. Soc. 41, 292.

Privett, O. S., Phillips, F., Shimasaki, H., Nozawa, T. \& Nickell, E. C. (1977). Am. f. clin. Nutr. 30, 1009 .

Privett, O. S., Stearns, E. M. \& Nickell, E. C. (1967). Y. Nutr. 92, 303 .

Pudelkewicz, C., Seufert, J. \& Holman, R. T. (1968). $\mathscr{7}$. Nutr. 94, 138.

Rand, P. G. \& Quackenbush, F. W. (1965). F. Nutr. 87, 498.

Renner, R. \& Hill, F. W. (1964). F. Nutr. 74, 254.

Sambasivaro, K. \& Brown, J. B. (1962). f. Am. Oil Chem. Soc. 39, 340.

Schrock, C. G. \& Connor, W. E. (1975). Am. J. clin. Nutr. 28, 1020.

Selinger, Z. \& Holman, R. T. (1965). Biochim. biophys. Acta 106, 56.

Soderhjelm, L., Wiese, H. F. \& Holman, R. T. (1971). In Progress in the Chemistry of Fats and other Lipids, vol, 9, p. 555 [R. T. Holman, editor]. Oxford: Pergamon Press.

Steele, W., Noble, R. C. \& Moore, J. H. (1971). Y. Dairy Res. 38, 49.

Strocchi, A. \& Holman, R. T. (1971). Olü Miner. 48,617.

Taylor, M. W. \& Hawke, J. C. (1975a). N.Z. F. Dairy Sci. Technol. ro, 40.

Taylor, M. W. \& Hawke, J. C. (1975b). N.Z. F. Dairy Sci. Technol. 10, 49.

Thomasson, H. J. (1953). In International Conference on Biochemical Problems of Lipids, Brussels; Koninklijke Vlaamse Academie voor Wetenschappen, Letteren en Schone Kunsten van Belgie, p. 212 .

Tidwell, H. C., Holt, L. E., Farrow, H. L. \& Neale, S. (1935). J. Pediat. 6, 48r.

Tomarelli, R. M., Meyer, B. J., Weaber, J. R. \& Bernhart, F. W. (r968). J. Nutr. 95, $5^{8} 3$. 
Vergroesen, A. J. \& Gottenbos, J. J. (1975). In The Role of Fats in Human Nutrition, p. 2 [A. J. Vergroesen, editor]. New York: Academic Press.

Viviani, R. (1970). Adv. Lipid Res. 8, 267.

Weigensberg, B. I. \& McMillan, G. C. (1964). J. Nutr. 83, 314.

Weigensberg, B. I., McMillan, G. C. \& Ritchie, A. C. (1961). Archs Path. 72, 126.

White, M. F. \& Brown, J. B. (1949). Y. Am. Oil Chem. Soc. 26, 385.

Woodruff, C. W., Bailey, M. C., Davis, J. T., Rogers, N. \& Coniglio, J. G. (Ig64). Am. F. clin. Nutr. 14, 83. 